\title{
PENGELOLAAN PEMBELAJARAN KIMIA PEMINATAN DAN LINTAS MINAT DI TINGKAT SMA
}

Kris Ayu Widiawati, Ketut Sudiana, Made Wiratini

Universitas Pendidikan Ganesha

A R T I C L E I N F O

Article history: Received 7 Januari 2019 Received in revised form 26 Januari 2019 Accepted 19 Maret 2019 Available online 30 April 2019

Kata Kunci: pengelolaan pembelajaran, peminatan, kesulitan belajar, lintas bidang

\begin{abstract}
Abstrak
Penelitian ini bertujuan untuk mendeskripsikan dan menjelaskan pengelolaan pembelajaran kimia peminatan dan lintas minat di SMA Negeri 1 Seririt. Penelitian ini dilaksanakan menggunakan pendekatan kualitatif dengan jenis penelitian fenomenologis. Subjek dalam penelitian ini yaitu guru kimia peminatan dan lintas minat, kepala SMA Negeri 1 Seririt, wakil kepala sekolah bidang kurikulum, penilai kinerja guru, serta siswa kelas X MIA 3 dan X BABUD 1. Metode pengumpulan data yang digunakan adalah studi dukumen, observasi, wawancara, dan kuisioner. Data penelitian dianalisis menggunakan teknik deskriptif kualitatif. Hasil penelitian ini adalah sebagai berikut. (1) Pemilihan peminatan MIA, IIS dan BABUD ditentukan berdasarkan nilai Raport dan UNBK siswa pada jenjang SMP, angket minat dan tes psikologis, sedangkan mata pelajaran lintas minat ditentukan langsung oleh pihak sekolah. (2) Pengelolaan pembelajaran kimia peminatan dan lintas minat meliputi perencanaan, pelaksanaan, penilaian dan pengawasan dibuat sama tanpa memperhatikan karakteristik siswa. Pengelolaan pembelajaran yang sama berimplikasi terhadap minat, hasil dan kesulitan belajar siswa. Minat belajar siswa kimia peminatan pada aspek sebelum dan saat mendapatkan pembelajaran kimia lebih tinggi dibandingkan kimia lintas minat. Persentase minat belajar siswa kimia peminatan sebelum mendapatan pembelajaran kimia sebesar 63,89\% dan kimia lintas minat sebesar 19,4\%. Persentase minat belajar siswa kimia peminatan saat mendapatkan pembelajaran kimia sebesar 69,44\% dan kimia lintas minat sebesar 33,11\%. Hasil belajar kimia peminatan lebih tinggi dibandingkan lintas minatyaitu 8,3\% di atas KKM dan di bawah KKM sebesar 91,7\%, sedangkan siswa kimia lintas minat yang mencapai KKM sebesar 2,8\% dan di bawah KKM sebesar $97,2 \%$.
\end{abstract}

\begin{abstract}
This study aims to describe and explain the management of chemistry learning specialization and crossinterest in SMA Negeri 1 Seririt. This research was carried out using a qualitative approach with a type of phenomenological research. Subjects in this study were chemistry specialization and cross-interest teachers, head of Seririt 1 Public High School, deputy headmaster in the curriculum field, teacher performance appraisers, as well as class X MIA 3 and X BABUD 1. Data collection methods used were document studies, observations, interview, and questionnaire. The research data were analyzed using qualitative descriptive techniques. The results of this study are as follows. (1) The selection of specialization of MIA, IIS and BABUD is determined based on the scores of the report cards and UNBK
\end{abstract}


students at the junior secondary level, interest questionnaires and psychological tests, while crossinterest subjects are determined directly by the school. (2) Management of specialization and crossinterest chemistry learning including planning, implementation, assessment and supervision is made equal regardless of student characteristics. The same management of learning has implications for interests, outcomes and student learning difficulties. Interest in specialization chemistry students in the aspects before and when they get chemistry learning is higher than cross-interest chemistry. The percentage of interest in specialization chemistry students before getting chemistry learning was $63.89 \%$ and cross-interest chemistry was $19.4 \%$. The percentage of interest in specialization chemistry students when getting chemistry learning was $69.44 \%$ and cross-interest chemistry was 33.11\%. Chemistry specialization learning outcomes are higher than cross interests, 8.3\% above KKM and below KKM 91.7\%, while chemistry students across interests reach KKM at 2.8\% and below KKM at 97.2\%.

Keywords: management of learning, specialization, cross interests, learning difficulties and interest in learning.

\section{PENDAHULUAN}

Minat merupakan salah satu faktor yang mempengaruhi hasil belajar. Tinggi rendahnya minat peserta didik terhadap satu pelajaran berbanding lurus terhadap tinggi rendah hasil belajar peserta didik. Sehingga guru dan pihak sekolah penting memperhatikan minat peserta didik dalam penentuan jurusan, karena hal ini akan berdampak pada proses pembelajaran. Guru akan lebih mudah mengelola pembelajaran untuk mencapai tujuan pembelajaran pada peserta didik yang memiliki minat tinggi dibandingkan dengan peserta didik yang memiliki minat rendah terhadap pembelajaran.

Menurut kurikulum 2013, di SMA terdapat program peminatan atau penjurusan yang meliputi MIA (Matematika dan Ilmu Alam, IIS (Ilmu-ilmu Sosial dan BABUD (Bahasa dan Budaya). Terkait dengan kebijakan tersebut pembelajaran kimia tidak hanya diberikan pada jurusan MIA, tetapi juga diberikan pada jurusan IIS dan BABUD yang mengambil lintas minat kimia. Adanya kebijakan tersebut, hendaknya pembelajaran kimia yang dibelajarkan pada peminatan dan lintas minat dibuat berbeda.

Pembelajaran adalah suatu proses interaksi antara peserta didik dengan pendidik dan sumber belajar pada suatu lingkungan belajar. Kegiatan pembelajaran dilakukan sebagai upaya mempengaruhi peserta didik untuk mencapai tujuan pendidikan yang telah ditetapkan. Guru sebagai fasilitator dalam pembelajaran memiliki peran penting dalam mengelola pembelajaran di kelas. Pada jenjang SMA pengelolaan pembelajaran dalam kurikulum 2013 dibedakan menjadi dua yaitu pengelolaan pembelajaran peminatan dan lintas minat.

Kurikulum 2013 yang dilaksanakan mengacu pada Standar Nasional Pendidikan yang bertujuan untuk menghasilkan sumber daya manusia yang memiliki kompetensi di bidangnya dan juga memiliki kemampuan untuk menguasai IPTEK. Kurikulum ini mengamanatkan bahwa pembelajaran merupakan proses sistematik untuk meningkatkan martabat manusia secara holistik yang memungkinkan potensi diri berkembang secara optimal (Kemendikbud, 2017). Penyusunan kurikulum 2013 dibedakan ke dalam mata pelajaran peminatan dan lintas minat dengan memperhatikan potensi, kecerdasan emosional, perkembangan minat, kecerdasan intelektual, sosial, dan spritual peserta didik. Berdasarkan Peraturan Pemerintah Republik Indonesia Nomor 13 Tahun 2015 tentang perubahan kedua atas Peraturan Pemerintah Republik Indonesia Nomor 19 Tahun 2005 Pasal 77B ayat (1) bagian a, b dan d disebutkan bahwa struktur kurikulum di SMA terdiri dari muatan umum, muatan peminatan akademik, dan muatan lintas minat atau pendalaman minat. Hal ini sesuai dengan Permendikbud Nomor 59 Tahun 2014 bahwa mata pelajaran dikelompokkan ke dalam mata pelajaran umum kelompok A, mata pelajaran umum kelompok B, peminatan akademik kelompok C yang terdapat pada kelas MIPA, IPS dan IPB. Dengan demikian, pembelajaran lintas minat pada jenjang SMA wajib dilakukan.

Menurut Kurikulum 2013, selain peserta didik mendapatkan mata pelajaran dalam suatu peminatan tertentu, peserta didik juga dapat mengambil mata pelajaran dari peminatan lain (lintas minat). Hal ini mewajibkan peserta didik untuk mempelajari mata pelajaran yang diminati, namun tidak terdapat pada kelompok pelajaran peminatan. Artinya, peserta didik yang jurusan kelas ilmu-ilmu sosial (IIS) juga akan mendapatkan mata pelajaran lintas minat MIA, demikian juga peserta didik yang jurusan Matematika dan Ilmu Alam (MIA) dapat mata pelajaran ilmu sosial. Program lintas minat dibuat berdasarkan minat, bakat atau kemampuan yang dimiliki peserta didik. Hal ini sesuai dengan UU Sisdiknas No. 20 Tahun 2003 pasal 12 ayat 1 butir b yang menyatakan peserta didik berhak mendapatkan pelayanan pendidikan sesuai dengan bakat, minat dan kemampuannya.

Mata pelajaran kimia juga didapatkan siswa peminatan IIS dan BABUD yang mengambil lintas minat kimia. Hal ini berimplikasi dalam pengelolaan pembelajaran yang dilakukan oleh guru kimia pada mata 
pelajaran peminatan dan lintas minat. Pengelolaan pembelajaran yang dimaksud disini meliputi perencanaan, pelaksanaan, penilaian dan pengawasan. Berdasarkan Permendikbud Nomor 22 Tahun 2016 tentang Standar Proses Pendidikan Dasar dan Menengah, perencanaan pembelajaran dirancang dalam bentuk Silabus dan Rencana Pelaksanaan Pembelajaran (RPP) yang mengacu Standar Isi. Penyusunan Silabus dan RPP disesuaikan pendekatan pembelajaran yang digunakan. Silabus merupakan acuan penyusunan kerangka pembelajaran untuk setiap bahan kajian mata pelajaran. Komponenkomponen yang ada dalam silabus terdiri atas Kompetensi Inti, Kompetensi Dasar, tema (khusus SD/MI/SDLB/Paket A), materi pokok, pembelajaran, penilaian, alokasi waktu dan sumber belajar. Silabus digunakan sebagai acuan dalam pengembangan pelaksanaan pembelajaran. Rencana Pelaksanaan Pembelajaran (RPP) adalah rencana kegiatan pembelajaran tatap muka untuk satu pertemuan atau lebih. RPP dikembangkan dari silabus untuk mengarahkan kegiatan pembelajaran peserta didik dalam upaya mencapai Kompetensi Dasar (KD). Berdasasarkan Permendikbud Nomor 22 Tahun 2016 tentang Standar Proses, pengelolaan pembelajaran harus memperhatikan karakteristik kompetensi yang meliputi karakteristik peserta didik, karakteristik materi serta sarana dan prasarana yang mendukung.

Berdasarkan studi pendahuluan yang dilakukan di SMA Negeri 1 Seririt menunjukkan pembelajaran yang diselenggarakan guru pada mata pelajaran kimia peminatan dan lintas minat dikelola sama, baik dari segi perencanaan, pelaksanaan dan penilaian. Perencanaan pembelajaran berupa RPP disusun dengan waktu dan kedalaman materi yang sama. Hal ini sejalan dengan hasil penelitian yang dilakukan oleh Christianto, Silaban, Verawaty dan Nurwahyuningsih (2016) bahwa materi yang diajarkan pada peminatan dan lintas minat sama. Guru dalam mengelola pembelajaran harus memperhatikan karakteristik peserta didik, karakteristik materi serta sarana dan prasarana yang mendukung, sehingga pengelolaan pembelajaran kimia peminatan dan lintas minat semestinya dibuat berbeda (Permendikbud Nomor 22 Tahun 2016).

Pemilihan mata pelajaran lintas minat secara teoritis ditentukan oleh minat peserta didik itu sendiri, tetapi fakta di lapangan menunjukkan bahwa pemilihan pembelajaran lintas minat ditentukan oleh pihak sekolah. Hal tersebut menyebabkan antusias peserta didik yang mempelajari mata pelajaran lintas minat lebih rendah dibandingkan dengan peserta didik yang mempelajari mata pelajaran peminatan, sehingga hasil belajar yang dicapai oleh peserta didik yang mempelajari mata pelajaran kimia lintas minat juga rendah. Hal ini telah dibuktikan dengan hasil penelitian yang dilakukan oleh Hastuti dan Yusi Iraning (2014) yang menunjukkan peserta didik yang mengikuti pembelajaran lintas minat memiliki semangat yang rendah dan banyak yang terlambat masuk kelas.

Hasil belajar peserta didik di SMA Negeri 1 Seririt yang mempelajari kimia lintas minat lebih rendah dibandingkan dengan kimia peminatan. Hal ini ditunjukkan dari persentase nilai ulangan harian yang diperoleh peserta didik kimia lintas minat di kelas X BABUD 1 sebesar 2,7\% mendapatkan nilai di atas KKM dan 97,2\% mendapatkan nilai di bawah KKM. Sedangkan persentase nilai ulangan harian peserta didik kimia peminatan di kelas X MIA 3 sebesar 27,8\% mendapatkan nilai di atas KKM dan 72,2\% mendapatkan nilai di atas KKM.KKM yang ditetapkan untuk mata pelajaran kimia peminatan dan lintas minat kelas X dibuat sama yaitu sebesar 70.

\section{METODE}

Penelitian ini menggunakan jenis penelitian fenomenologis dengan pendekatan kualitatif. Lokasi penelitian ini yaitu di SMA Negeri 1 Seririt yang terletak di Jalan Diponegoro No. 100, Kecamatan Seririt, Kabupaten Buleleng. Subjek yang diteliti adalah guru kimia peminatan dan lintas minat, kepala SMA Negeri 1 Seririt, wakil kepala sekolah bidang kurikulum, penilai kinerja guru serta siswa kelas X MIA 3 dan $\mathrm{X}$ BABUD 1. Aktivitas yang diteliti pada penelitian ini yaitu tentang pengelolaan pembelajaran kimia peminatan dan lintas minat yang meliputi perencanaan, pelaksanaan, penilaian dan pengawasan. Data penelitian ini dikumpulkan dengan menggunakan teknik wawancara, observasi, studi dokumen dan kuisioner. Teknik analisis data pengelolaan pembelajaran menggunakan deskriptif kualitatif dan angket dianalisis dengan menggunakan teknik Method of Succecive Interval (MSI).Pada penelitian ini, pengujian keabsahan data dilakukan dengan menggunakan metode triangulasi sumber. Ketika melakukan triangulasi data dengan teknik wawancara maka perlu dilakukan member check.Tujuan dari member check adalah untuk mengetahui seberapa jenuh data yang diperoleh sesuai dengan apa yang diberikan oleh pemberi data.

\section{HASIL DAN PEMBAHASAN}

Penelitian ini dilakukan di SMA Negeri 1 Seririt tentang pengelolaan pembelajaran kimia peminatan dan lintas minat. Pengelolaan pembelajaran kimia peminatan terdapat di kelas MIA, sedangkan kimia lintas minat terdapat di kelas BABUD. Pemilihan peminatan di SMA Negeri 1 Seririt ditentukan berdasarkan nilai pada jenjang SMP (Sekolah Menengah Pertama), tes psikologis dan minat peserta didik, 
sedangkan pemilihan mata pelajaran lintas minat ditentukan langsung oleh pihak sekolah. Berdasarkan hasil wawancara yang dilakukan terhadap koordinator bimbingan konseling, acuan utama pemilihan program peminatan adalah nilai raport peserta didik pada jenjang SMP. Nilai raport yang rata-ratanya tinggi akan dijuruskan ke peminatan MIA dan nilai raport yang rendah akan dijuruskan ke peminatan IIS dan BABUD. Di samping menggunakan acuan ini, sekolah juga memberikan angket minat dan tes psikologis kepada peserta didik sebagai pertimbangan penjurusan peminatan. Hal ini sesuai dengan Permendikbud RI Nomor 64 Tahun 2014 tentang Peminatan pada Pendidikan Menengah ayat 1 dan 2 bahwa syarat program peminatan harus berdasarkan kemampuan akademik, minat, dan bakat peserta didik. Hal yang dipertimbangkan yaitu nilai raport peserta didik pada jenjang sebelumnya, nilai ujian nasional, dan rekomendasi dari guru bimbingan konseling. Hasil penelitian ini sejalan dengan penelitian yang dilakukan oleh Cahayani \& Lukitaningsih (2014) bahwa langkah-langkah pemilihan peminatan SMA yaitu secara akademik dan non akademik. Secara akademik pemilihan peminatan ditentukan dengan menyeleksi nilai Raport dan UN peserta didik, sedangkan secara non akademik ditentukan dengan melihat minat dan bakat peserta didik melalui, tes psikologis (IQ peserta didik di atas 110 mendapatkan peminatan MIA dan IQ di bawah 100 mendapatkan peminatan IIS dan BABUD), TPA dan angket minat.

Pemberian mata pelajaran lintas minat ditentukan langsung oleh pihak sekolah dengan pertimbangan pemenuhan jam mengajar guru. Artinya, pemberian mata pelajaran lintas minat disesuikan dengan jam mengajar guru minimal 24 JS. Hal tersebut akan berdampak pada minat dan aktivitas belajar peserta didik di kelas. Hasil analisis angket menunjukkan bahwa peserta didik yang berminat sebelum mendapatkan mata pelajaran kimia di kelas X BABUD 1 lebih rendah dibandingkan dengan peserta didik X MIA 3. Peserta didik kelas X MIA 3 yang berminat terhadap pembelajaran kimia sebanyak 23 orang $(63,89 \%)$ dan yang tidak berminat sebanyak 13 orang $(36,11 \%)$. Sedangkan peserta didik di kelas BABUD yang berminat terhadap pembelajaran kimia sebanyak 7 orang $(19,4 \%)$ dan yang tidak berminat sebanyak 29 orang (80,56\%). Berikut ini merupakan tabel hasil analisis minat belajar kimia siswa sebelum mendapatkan pembelajaran kimia.

Tabel 1. Sebaran Minat Belajar Kimia Peminatan (MIA) dan Lintas Minat (BABUD) Sebelum Mendapatkan Pembelajaran Kimia

\begin{tabular}{ccccc}
\hline Kimia/Kelas & Berminat & (\%) Berminat & $\begin{array}{c}\text { Tidak } \\
\text { Berminat }\end{array}$ & $\begin{array}{c}\text { (\%) Tidak } \\
\text { Berminat }\end{array}$ \\
\hline $\begin{array}{c}(1) \\
\begin{array}{c}\text { Peminatan } \\
\text { (MIA) }\end{array}\end{array}$ & 23 orang & 63,89 & 13 orang & 36,11 \\
\hline $\begin{array}{c}\text { Lintas Minat } \\
\text { (BABUD) }\end{array}$ & 7 orang & $19,4 \%$ & 29 orang & 80,56 \\
\hline
\end{tabular}

Perbedaan minat belajar peserta didik sebelum mendapatkan pembelajaran kimia juga dapat digambarkan pada Gambar 1.

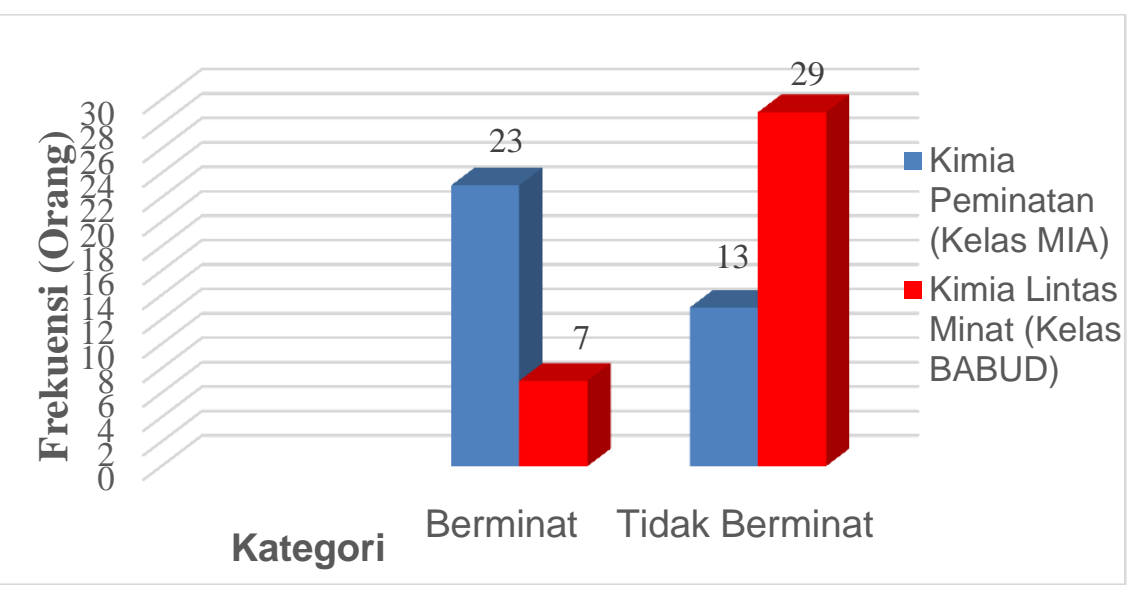

Gambar 1. Sebaran Minat Belajar Kimia Peminatan (MIA) dan Lintas Minat (BABUD) Sebelum Mendapatkan Pembelajaran Kimia. 
Minat peserta didik dalam belajar akan mempengaruhi proses pengelolaan pembelajaran yang dilaksanakan guru. Pengelolaan pembelajaran yang dianalisis terdiri dari 4 aspek yaitu tahap perencanaan, pelaksanaan, penilaian, dan pengawasan. Terdapat beberapa faktor-faktor yang mempengaruhi pengelolaan pembelajaran diantaranya yaitu (1) faktor guru, (2) faktor peserta didik, (3) faktor sarana dan prasarana, (4) faktor lingkungan (Soetjipto dan Kosasi, 2009). Perencanaan pembelajaran yang diteliti adalah berupa silabus dan RPP. Pelaksanaan pembelajaran yang diteliti berupa proses pembelajaran yang dilakukan oleh guru di kelas. Penilaian yang diteliti berupa hasil belajar kimia peserta didik yaitu ulangan akhir semester (UAS) dan dibandingkan dengan kriteria ketuntasan minimal (KKM) antara kelas peminatan dan lintas minat. Terakhir yang diteliti yaitu pengawasan pengelolaan pembelajaran yang dilakukan oleh tim supervisi. Tim supervisi yang dimaksud dalam penelitian ini yaitu kepala sekolah, wakil kepala sekolah bidang kurikulum, dan penilai kinerja guru. Adapun deskripsi tentang pengelolaan pembelajaran kimia peminatan dan lintas minat dapat dijelaskan sebegai berikut.

\section{Perencanaan Pembelajaran}

Perencanaan pembelajaran dirancang dalam bentuk Silabus dan Rencana Pelaksanaan Pembelajaran (RPP) yang mengacu pada Standar Isi. Berdasarkan Permendikbud Nomor 22 Tahun 2016 tentang standar proses, RPP dibuat dengan memperhatikan perbedaan individual peserta didik antara lain kemampuan awal, tingkat intelektual, bakat, potensi, minat, motivasi belajar, kemampuan sosial, emosi, gaya belajar, kebutuhan khusus, kecepatan belajar, latar belakang budaya, norma, nilai, daa lingkungan peserta didik. Hasil penelitian yan dilakukan, diperoleh perencanaan pembelajaran yang meliputi Silabus dan RPP mata pelajaran Kimia antara peserta didik peminatan dan lintas minat dibuat sama. Menurut guru mata pelajaran kimia yang mengampu kimia peminatan dan lintas minat, perencanaan pembelajaran yang direncanakan mulai dari KD, tujuan pembelajaran, indikator ketercapaian, dan strategi pembelajaran dibuat sama. Perencanaan dibuat sama dikarenakan materi dan waktu yang diberikan sama. Hal yang sama juga dijelaskan oleh Kepala Sekolah dan Wakil Kepala Sekolah Bidang Kurikulum bahwa perencanaan pembelajaran peminatan dan lintas minat dapat dibuat sama dikarenakan kedalaman materi dan juga waktu yang diberikan sama. Hal ini berarti perencanaan pembelajaran kimia peminatan dan lintas minat dibuat sama, karena tidak ada perbedaan silabus yang diberikan oleh pusat. Hasil penelitian ini sejalan dengan penemuan Christianto, dkk (2016) yang menyatakan materi pelajaran yang diajarkan antara peminatan dan lintas minat dibuat sama karena silabus materi pelajaran lintas minat kimia yang belum tersedia.

\section{Pelaksanaan Pembelajaran}

Pelaksanaan pembelajaran merupakan imlplementasi dari RPP, meliputi kegiatan pendahuluan, inti, dan penutup (Permendikbud Nomor 22 Tahun 2016). Pelaksanaan pembelajaran yang baik merupakan pelaksanaan pembelajaran yang dilaksanakan sesuai dengan perencanaan yang disusun dalam RPP.

Pelaksanaan pembelajaran oleh guru antara peminatan dan lintas minat kimia di SMA Negeri 1 Seririt dibuat sama. Berdasarkan hasil observasi yang dilakukan di kelas X MIA 3 dan X BABUD 1 proses pelaksanaan pembelajaran kimia peminatan dan lintas minat disamakan. Hal tersebut dikarenakan perencanaan yang dibuat sama, sehingga guru menerapkan proses pembelajaran yang sama antara peserta didik pada peminatan dan lintas minat kimia. Artinya guru melaksanakan proses pembelajaran di kelas sesuai dengan perencanaan yang telah dibuat.

Pada aktivitas pembelajaran ini terlihat peserta didik peminatan lebih aktif berinteraksi dalam proses pembelajaran dibandingkan dengan peserta didik lintas minat. Hal ini ditunjukkan dari hasil obervasi bahwa banyak peserta didik peminatan yang merespon pertanyaan guru. Sedangkan untuk peserta didik lintas minat sebagian besar kurang aktif. Berdasarkan hasil wawancara yang dilakukan dengan guru kimia, perbedaan aktivitas siswa di peminatan dan lintas minat kimia dipengaruhi oleh minat dan antusias siswa dalam mengikuti pembelajaran kimia. Minat yang dimiliki oleh peserta didik akan mempengaruhi hasil belajar. Semakin tinggi minat belajar siswa maka hasil belajar yang diperoleh juga semakin baik. Berdasarkan hasil ulangan akhir semester, rata-rata nilai kimia peminatan yang didapatkan oleh kelas X MIA 3 lebih tinggi dibandingkan dengan kimia lintas minat yang diperoleh oleh kelas X BABUD 1. Rata-rata nilai ulangan akhir semester genap kimia peminatan sebesar 49,89 sedangkan rata-rata nilai ulangan akhir semester genap kimia lintas minat sebesar 42,11. Peserta didik yang mencapai nilai di atas KKM pada pembelajaran kimia peminatan sebesar 8,3\% dan di bawah KKM sebesar 91,7\%, sedangkan peserta didik yang mencapai KKM sebesar 2,8\% dan di bawah KKM sebesar 97,2\%. Hasil penelitian ini sejalan dengan penelitian yang dilakukan oleh Ermelinda \& Benge (2017) bahwa minat belajar peserta didik akan membangkitkan motivasi peserta didik dalam belajar, sehingga aktivitas dan hasil belajar peserta didik dalam pembelajaran akan lebih tinggi. Hal yang sama juga 
ditemukan oleh Peter James (2014) bahwa terdapat hubungan yang signifikan antara minat dan hasil belajar.

Proses pembelajaran yang kurang aktif pada peserta didik lintas minat erat kaitannya dengan hasil wawancara peserta didik pada kelas X BABUD 1 yang menyatakan sebagaian besar tidak berminat terhadap pembelajaran kimia. Berbeda dengan kelas X MIA 1 sebagian besar peserta didik berminat dengan pembelajaran kimia. Berdasarkan hasil wawancara dengan peserta didik kelas X BABUD 1, perbedaan minat tersebut dikarenakan materi pembelajaran kimia yang dianggap sulit, sehingga berdampak pada minat dan aktivitas belajar di kelas. Hal ini didukung dengan hasil analisis angket peserta didik bahwa di kelas X MIA 1 peserta didik yang berminat dengan pembelajaran kimia sebanyak 25 orang $(69,44 \%)$ dan yang tidak berminat sebanyak 11 orang $(30,56 \%)$. Sedangkan di kelas X BABUD 1 yang berminat dengan pembelajaran kimia sebanyak 13 orang $(36,11 \%)$ dan yang tidak berminat sebanyak 23 orang $(63,89 \%)$. Hasil penelitian ini sejalan dengan hasil temuan oleh Meliawati dan kawankawan (2016), bahwa sebagian besar peserta didik kurang berminat dengan pembelajaran lintas minat, sehingga guru sulit mengkondisikan kegiatan belajar peserta didik di kelas. Berikut ini merupakan tabel hasil analisis minat belajar kimia siswa saat mendapatkan pembelajaran kimia.

Tabel 2. Sebaran Minat Belajar Kimia Peminatan (MIA) dan Lintas Minat (BABUD) Saat Mendapatkan Pembelajaran Kimia

\begin{tabular}{ccccc}
\hline Kimia/Kelas & Berminat & $\begin{array}{c}(\%) \\
\text { berminat }\end{array}$ & Tidak Berminat & $\begin{array}{c}(\%) \\
\text { tidak beminat }\end{array}$ \\
\hline (1) & $(2)$ & $(3)$ & $(4)$ & $(5)$ \\
Peminatan (MIA) & 25 orang & 69,44 & 11 orang & 36,11 \\
Kimia Lintas & 13 orang & 30,56 & 23 orang & 63,89 \\
(BABUD) & & & & \\
\hline
\end{tabular}

Perbedaan minat belajar peserta didik sebelum mendapatkan pembelajaran kimia juga dapat digambarkan pada Gambar 2.

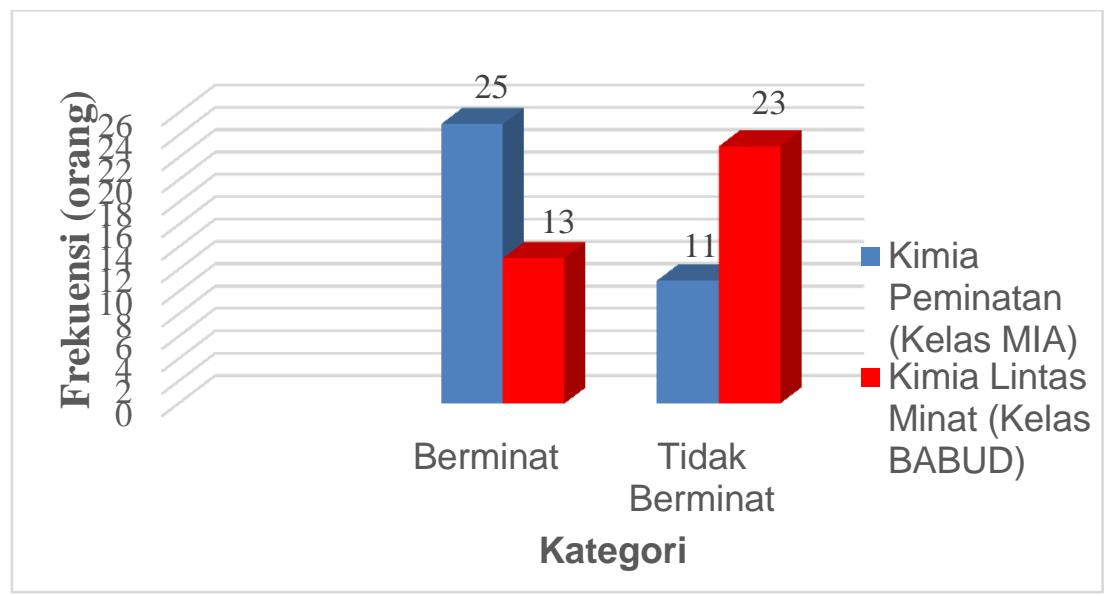

Gambar 2. Sebaran Minat Belajar Kimia Peminatan (MIA) dan Lintas Minat (BABUD) Saat Pembelajaran Berlangsung

3. Penilaian Pembelajaran

Penilaian adalah proses pengumpulan dan pengolahan informasi untuk mengukur pencapaian hasil belajar peserta didik (Permendikbud Nomor 23 Tahun 2016). Berdasarkan hasil pencermatan RPP dan observasi penilaian yang dilakukan adalah pada aspek penilaian sikap, pengetahuan dan keterampilan. Penilaian sikap yang dinilai berupa empat aspek yaitu: bekerja sama, jujur, tanggung jawab, dan disiplin yang diukur dengan menggunakan instrumen penilaian observasi. Pada aspek pengetahuan yang dinilai yaitu ulangan harian dan ulangan akhir semester. Pada aspek keterampilan yang dinilai adalah fortopolio, proyek, dan produk. Berdasarkan studi dokumen yang dilakukan, penilaian hasil belajar kimia peminatan dan lintas minat diukur dengan jenis soal yang sama. Hal tersebut dikarenakan materi kimia, indikator pencapaian tujuan pembelajaran dan KKM yang diberikan sama. Artinya tidak ada perbedaan penilaian hasil belajar yang berikan antara peserta didik kimia peminatan dan lintas minat.

Berdasarkan hasil wawancara dengan guru kimia, KKM mata pelajaran kimia peminatan dan lintas kimia kelas X sebesar 70. KKM kimia yang ditetapkan sebesar 70 disesuaikan dengan pertimbangan 
kesepakatan tim pengembang kurikulum. Hal ini berarti guru tidak memperhatikan kemampuan awal (intake) peserta didik sebelum mendapatkan pembelajaran kimia. Penetapan KKM mata pelajaran seharusnya memperhatikan tiga aspek penilaian yaitu intake, daya dukung dan kompleksitas (Direktorat Pembinaan SMA, 2010).

\section{Pengawasan Pembelajaran}

Pengawasan merupakan pemantauan proses pembelajaran yang dilakukan pada tahap perencanaan, pelaksanaan, dan penilaian hasil pembelajaran. Pengawasan pengelolan pembelajaran dilakukan oleh pengawas internal dan pengawas eksternal. Pengawas internal dilakukan oleh tim supervisi yaitu: kepala sekolah, wakil kepala sekolah bidang kurikulum, dan tim penilai kinerja guru (PK Guru). Pengawas eksternal merupakan pengawas dari dinas Disdik Provinsi Bali.

Hasil wawancara dengan kepala sekolah SMA Negeri 1 Seririt, proses pengawasan yang dilakukan yaitu: (1) pengecekan administrasi guru; (2) pengawasan proses pembelajaran; dan (3) dilaksanakan dengan tindak lanjut terhadap proses pengawasan yang diamati. Pengawasan dilakukan kurang lebih 1 sampai 3 kali dalam setahun. Adapun temuan-temuan yang diperoleh selama melakukan pengawasan yaitu penggunaan waktu yang kurang efektif dalam pembelajaran dan guru dalam melaksanakan proses pembelajaran tidak sesuai dengan RPP. Tindak lanjut dari temuan ini adalah memberikan masukan terkait penggunakan waktu yang lebih efektif serta memberikan pelatihan-pelatihan atau workshop kepada guru-guru yang belum menguasai sintak pembelajaran di beberapa model pembelajaran kurikulum 2013. Dilihat dari proses pengawasan yang dilakukan sudah cukup baik. Pengawasan internal yang baik akan memberikan dampak positif pada peningkatan disiplin guru dan peserta didik, dan peningkatan kualitas administrasi guru (Wiratma, 2013).

Berdasarkan deskripsi di atas, pengelolaan pembelajaran kimia peminatan dan lintas minat disamakan. Hal ini dikarenakan silabus, KKM, materi dan waktu yang diberikan sama. Berdasarkan Permendikbud Nomor 22 Tahun 2016 tentang Standar Proses, pengelolaan pembelajaran yang dibuat semestinya mempertimbangkan karakteristik peserta didik. Hasil penelitian ini menunjukkan guru tidak memperhatikan karakteristik peserta didik dalam mengelola pembelajaran. Hasil penelitian oleh Budiningsih (2011) menemukan bahwa masih banyak pelaksanaan pembelajaran yang kurang memperhatikan karakteristik peserta didik, kegiatan pembelajaran semata-mata hanya untuk menyelesaikan program-program yang tertuang di dalam kurikulum. Hal tersebut akan berimplikasi pada aktivitas belajar peserta didik yang dibuktikan dengan hasil belajar peserta didik peminatan lebih besar dibandingkan lintas minat. Rata-rata nilai ulangan akhir semester genap kimia peminatan sebesar 49,89 sedangkan rata-rata nilai ulangan akhir semester genap kimia lintas minat sebesar 42,11. Peserta didik yang mencapai nilai di atas KKM pada pembelajaran kimia peminatan sebesar 8,3\% dan di bawah KKM sebesar 91,7\%, sedangkan peserta didik yang mencapai KKM sebesar 2,8\% dan di bawah KKM sebesar $97,2 \%$.

Dampak lain dari pengelolaan pembelajaran yang dibuat sama yaitu rendahnya minat belajar peserta didik yang mempelajari lintas minat kimia. Hal ini dibuktikan dari analisis angket minat belajar menggunakan Method of Succecive Interval (MSI) yang menunjukkan peserta didik yang berminat dengan proses pembelajaran kimia peminatan sebesar $69,44 \%$, sedangkan peserta didik yang berminat dengan proses pembelajaran kimia lintas minat sebesar 30,56\%. Minat yang rendah merupakan salah satu faktor munculnya kesulitan belajar pada peserta didik. Semakin rendah minat belajar peserta didik maka kesulitan belajarnya akan semakin tinggi. Hasil penelitian yang dilakukan oleh Rahmadani, W., Harahap, F., \& Gultom, T (2017), menemukan bahwa kesulitan belajar peserta didik dapat dipengaruhi oleh minat, motivasi dan bakat peserta didik dengan persentase sebesar $43 \%$.

\section{Simpulan dan Saran}

Berdasarkan hasil penelitian di atas, dapat disimpulkan bahwa pengelolaan pembelajaran kimia peminatan dan lintas minat dibuat sama. Berikut diuraikan simpulan pengelolaan pembelajaran kimia peminatan dan lintas minat. (1) RPP kimia peminatan dan lintas minat dibuat sama dikarenakan kedalaman materi dan waktu yang tersedia sama. Hal ini berarti guru belum memperhatikan karakteristik peserta didik dalam merencanakan pembelajaran. (2) Pelaksanaan pembelajaran kimia peminatan dan lintas minat dibuat sama dikarenakan RPP yang digunakan sama. Artinya strategi pembelajaran yang guru dalam melaksanakan proses pembelajaran kimia peminatan dan lintas minat sama. (3) Penilaian pembelajaran meliputi tes hasil belajar dan penentuan KKM peserta didik di kelas peminatan dan lintas minat disamakan. Hal ini dikarenakan indikator ketercapaian hasil belajar sama. Hal ini berarti guru tidak memperhatikan kemampuan peserta didik dalam memberikan penilaian pembelajaran. (4) Pengawasan pembelajaran di SMA Negeri 1 Seririt dilakukan oleh pengawas internal (kepala sekolah, wakil kepala sekolah dan penilai kinerja guru) sedangkan pengawas eksternal dilakukan oleh Dinas Pendidikan 
Provinsi Bali. Pengawasan yang dilakukan meliputi perencannaan, pelaksanaan, dan penilaian atau evaluasi. Kendala-kendala yang ditemukan saat proses pengawasan yaitu penggunaan waktu yang kurang efektif dalam pembelajaran dan proses pembelajaran yang tidak sesuai dengan perencanaan yang dibuat. Tindak lanjut dari kendala-kendala tersebut yaitu memberikan masukan kepada guru terkait hal-hal yang perlu diperbaiki dan memberikan pelatihan-pelatihan berupa workshop kepada guru-guru tentang sintak pembelajaran di beberapa model pembelajaran kurikulum 2013.

Berdasarkan hasil penelitian ini disampaikan beberapa saran sebagai berikut. (1) Pemilihan peminatan dan lintas minat sebaiknya dipilih berdasarkan minat, bakat dan kemampuan peserta didik. Hal ini akan dapat mempengaruhi proses pembelajaran di kelas dan hasil belajar siswa. (2) Pengelolaan pembelajaran semestinya dibuat berdasarkan karakteristik peserta didik, sehingga ketercapaian hasil belajar menjadi lebih maksimal.

\section{DAFTAR PUSTAKA}

Budiningsih, A. 2011. Karakteristik Siswa sebagai Pijakan dalam Penelitian dan Metode Pembelajaran. Jurnal Cakrawala Pendidikan. 1(1) pp 160-173

Christianto,H., Silaban,R., Verawaty M., \& Nurwahyuningsih. 2016. Analisis Pembelajaran Lintas Minat Kimia di Kelas X Dan XI IIS SMAK Bintang Laut Bagansiapi-siapi-Riau. Prosiding Seminar Nasional Kimia dan Pendidikan Kimia 2016. Medan: Universitas Medan Press.

Ekpenyong, E. E., Edem, A. O., \& Martin, I.O. 2015. Student's Interest in Social Studies and Academic Achievement in Tertiary Institutions in Cross River State, Nigeria. European Journal of Training and Development Studies.2(2) pp 35-40.

Ermelinda \& Benge. 2017. Hubungan antara Minat dan Motivasi Belajar IPA Pada Siswa SD. Journal of Education Technology. 1(4) pp 231-238.

Kemendikbud. 2017. Model Peminatan dan Lintas Minat. Jakarta: Kemendikbud.

Peraturan Menteri Pendidikan dan Kebudayaan Nomor 22 Tahun 2016 tentang Standar Proses Pendidikan Dasar dan Menengah.2016. Jakarta: Depdiknas.

Peraturan Menteri Pendidikan dan Kebudayaan Nomor 23 Tahun 2016tentang Standar Penilaian. 2016. Jakarta: Depdiknas.

Peraturan Menteri Pendidikan dan Kebudayaan Nomor 59 Tahun 2014 tentang Kurikulum 2013 Sekolah Menengah Atas/Madrasah Aliyah. 2014. Jakarta: Depdiknas.

Peraturan Menteri Pendidikan dan Kebudayaan Nomor 64 Tahun 2014 tentang Peminatan Pada Pendidikan Menengah. 2014. Jakarta: Depdiknas.

Peraturan Pemerintah Republik Indonesia Nomor 13 Tahun 2015 tentang Perubahan Kedua Atas Peraturan Pemerintah Nomor 19 Tahun 2005 tentang Standar Nasional Pendidikan . 2013. Jakarta: Depdiknas.

Peraturan Pemerintah Republik Indonesia Nomor 19 Tahun 2005 tentang Standar Nasional Pendidikan. 2005. Jakarta: Depdiknas.

Peter James, 2014Academic Achievement Prediction : Role of Interest in Learning and Attitude towards School, International Journal of Humanities Social Science and Education (IJHSSE), Volume 1, PP 73100.

Cahayani, N \& Lukitaningsih, R. 2014. Pelaksanaan Bimbingan dan Konseling dalam Pelayanan Peminatan Akademik Kurikulum 2013 di SMAN 1 Sooko Mojokerto. Jurnal BK. 4(3) pp 659-666.

Wiratma, I.G.L. 2013. Pengelolaan Pembelajaran Kimia pada SMAN 1 Singaraja dan SMAN 1 Gianyar: Dekontruksi Implementasi Standar Proses. Disertasi (tidak diterbitkan). Program Studi Kajian Budaya, Program Pascasarjana Universitas Udayana.

Rahmadani, W., Harahap, F., \& Gultom, T. 2017. Analisis Faktor Kesulitan Belajar Biologi Siswa Materi Biteknologi di SMA Negeri Se-Kota Medan. Jurnal Pendidikan Biologi. 6(2). 